\title{
Effect of Austempering-Partitioning on the Bainitic Transformation and Mechanical Properties of a High-Carbon Steel
}

\author{
Bo Han · Lei Chen $\cdot$ Su-Jun Wu
}

Received: 18 October 2014/Revised: 7 December 2014/Published online: 5 March 2015

(C) The Chinese Society for Metals and Springer-Verlag Berlin Heidelberg 2015

\begin{abstract}
The $1.1 \mathrm{C}-1.5 \mathrm{Si}-1.1 \mathrm{Mn}-1.4 \mathrm{Cr}-0.5 \mathrm{Mo}-0.6 \mathrm{Al}-0.6 \mathrm{Co}$ (in wt $\%$ ) steel was treated, respectively, by isothermal austempering process and newly developed austempering-partitioning-tempering process (A-P-T). After austempering at 250,280 and $300{ }^{\circ} \mathrm{C}$ for 38,20 and $10 \mathrm{~h}$, respectively, the sample microstructures were composed of bainitic ferrite plates and film-like retained austenite with thicknesses between 60 and $150 \mathrm{~nm}$. The highest tensile strength of $2003 \mathrm{MPa}$ and hardness value of $53.9 \mathrm{HRC}$ were obtained for the steel after austempering at $250{ }^{\circ} \mathrm{C}$ for $38 \mathrm{~h}$, resulting from the combining effect of super-saturated martensite decarburization and stabilization of bainitic formation. After A-P-T treating (heated at $300{ }^{\circ} \mathrm{C}$ for $8 \mathrm{~h}$ following water cooling, and then heated at $300{ }^{\circ} \mathrm{C}$ for $2 \mathrm{~h}$ following air cooling), bamboo leaf-like martensite, primary and secondary bainites and retained austenite were observed. The thickness of the secondary bainitic ferrite plates formed during partitioning is much smaller than that of the primary bainite formed during $300{ }^{\circ} \mathrm{C}$ austempering. Samples subjected to A-P-T treatment showed improvement in ductility compared to that subjected to austempering.
\end{abstract}

KEY WORDS: High-carbon alloy steel; Low-temperature bainite; Microstructure; Mechanical properties; Austempering-partitioning-tempering

\section{Introduction}

Low-temperature bainite has fine microstructures and ultimate tensile strength. Studies on steels containing about $0.8 \mathrm{wt} \% \mathrm{C}$ have revealed that mechanical properties of an ultimate tensile strength of $2500 \mathrm{MPa}$, hardness of 600-670 HV and toughness more than $30-40 \mathrm{MPa} \mathrm{m}^{1 / 2}$ can be achieved through the formation of a low-temperature bainitic microstructure. These bainites composed of plates of bainitic ferrite and films of retained austenite have benefited from its slender plates of ferrite by

Available online at http://link.springer.com/journal/40195

B. Han $\cdot$ L. Chen $\cdot$ S.-J. Wu $(\bowtie)$

School of Materials Science and Engineering, Beihang

University, Beijing 100191, China

e-mail: wusj@buaa.edu.cn isothermal transformation at $200{ }^{\circ} \mathrm{C}$. Moreover, adding $\sim 2 \mathrm{wt} \% \mathrm{Si}$, the precipitation of cementite from austenite can be retarded, which leads to a carbide-free bainitic microstructure [1-3]. To obtain ideal microstructure, various heat treatment procedures have been applied to different steels. It was reported that a low-temperature bainite microstructure can be obtained for 60Si2 CrVA steel after isothermal bainitic transformation treatment at $235^{\circ} \mathrm{C}$, and the tensile strength of the steel can be achieved as $\sim 1980 \mathrm{MPa}$ [4]. The low-temperature bainite was gained in $40 \mathrm{SiMnNiCr}$ steel subjected to $\mathrm{Q} \& \mathrm{P}$ process (quenched at $180{ }^{\circ} \mathrm{C}$ for $60 \mathrm{~s}$ and partitioned at $300{ }^{\circ} \mathrm{C}$ for $120 \mathrm{~s}$ ), which resulted in an ultimate tensile strength of $\sim 2000 \mathrm{MPa}$ [5]. A novel quenching-partitioning-tempering (Q-P-T) treatment was applied to $0.2 \mathrm{C}-1.5 \mathrm{Mn}-$ $1.5 \mathrm{Si}-0.6 \mathrm{Cr}-0.05 \mathrm{Nb}(\mathrm{wt} \%)$ steel, and it resulted in about $10 \mathrm{vol} \%$ retained austenite in the steel, compared to about nil percent retained austenite after the traditional 
(a)

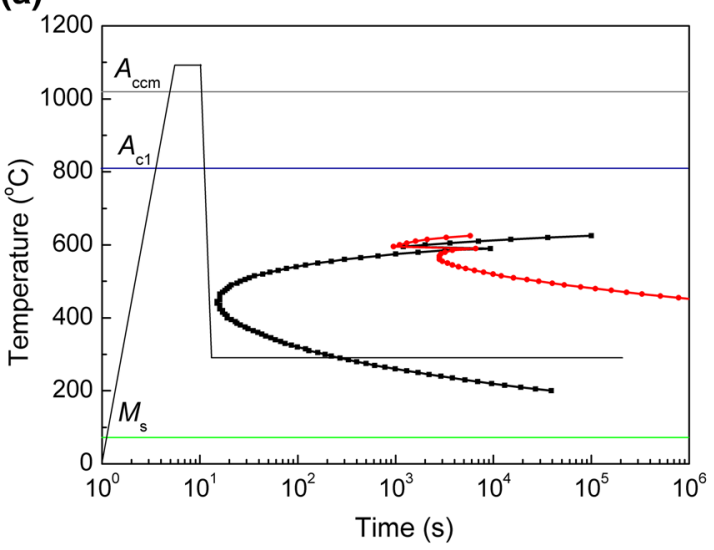

(b)

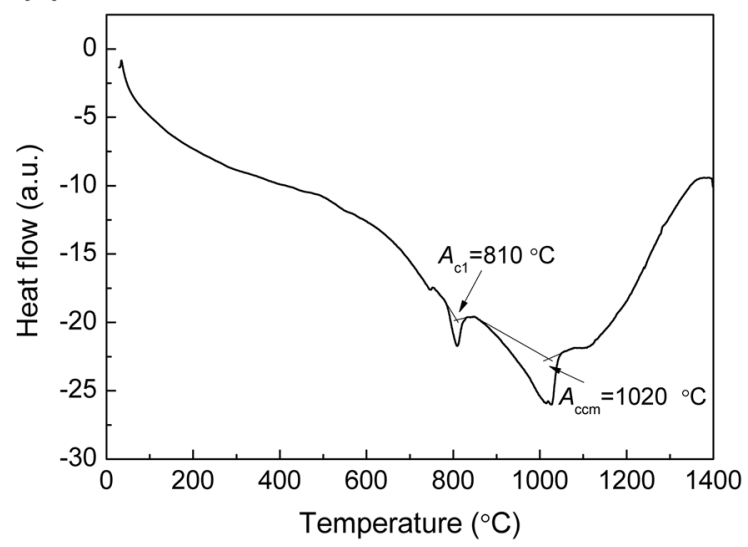

Fig. 1 a Calculated TTT diagram for initiation of bainitic transformation determining; b measured differential thermal analysis (DTA) diagram for phase transformation temperature determining

quenching-tempering treatment, which can influence the stress-strain property considering the possible strain-induced austenite-martensite transformation [6]. Low-temperature nanobanitic structure was obtained for the steel with 0.85 wt $\% \mathrm{C}$, through two-step austempering, which gave a high tensile strength of $1955 \mathrm{MPa}$ with a total elongation of $7 \%$ [7]. The effect of a relatively high isothermal temperature $\left(400{ }^{\circ} \mathrm{C}\right)$ on the microstructure of a low-carbon, high-Al low-Si steel was studied, and the bainite structure produced a high product of tensile strength and elongation as $17,685 \mathrm{MPa} \%$ [8]. In-situ observation was carried out to analyze the bainite transformation behavior of a low-carbon steel under the tensile loading [9]. However, the effect of isothermal temperature and content of carbon on bainitic transformation need to be further discussed.

Bainitic transformation and the effect on mechanical properties have been widely studied for steels with relatively low-carbon contents. However, studies on lowtemperature bainitic steels with more than $1 \mathrm{wt} \% \mathrm{C}$ are seldom reported. In this study, a special heat treatment procedure of A-P-T was developed. Studies were carried out on the evolution of the bainitic and martensitic structures of an ultra-high-strength steel with $1.05 \mathrm{wt} \%$ carbon. Mechanical tests were performed to reveal the relationship between the microstructure and the mechanical properties of the high-carbon steel.

\section{Experimental Procedures}

The investigated steel is a high-carbon steel with the composition (wt\%) of $\mathrm{Fe}-1.1 \mathrm{C}-1.5 \mathrm{Si}-1.1 \mathrm{Mn}-1.4 \mathrm{Cr}-$ $0.5 \mathrm{Mo}-0.6 \mathrm{Al}-0.6 \mathrm{Co}$, because the high carbon would prolong the initiation period of bainitic transformation, and the $\mathrm{Co}$ and $\mathrm{Al}$ were added to accelerate the initiation of bainitic transformation [2]. Based on the phase transformation software MUCG 83 [10], the phase transformation behavior of the concerned experimental steel was analyzed. Figure 1a shows the calculated TTT diagram for the initiation of the bainitic transformation determining. DTA was employed to measure the $A_{\mathrm{cl}}, A_{\mathrm{ccm}}$ of the steel with heating rate of $10^{\circ} \mathrm{C} / \mathrm{min}$ from ambient temperature to $1400{ }^{\circ} \mathrm{C}$, as shown in Fig. 1b. It can be found that the $A_{\mathrm{c} 1}$ and $A_{\mathrm{ccm}}$ of the experimental steel are 810 and $1020^{\circ} \mathrm{C}$, respectively. The $M_{\mathrm{s}}$ temperature of the steel was calculated by MUCG 83 [10] to be $\sim 180{ }^{\circ} \mathrm{C}$, which is similar to $\sim 189^{\circ} \mathrm{C}$, what was calculated by empirical equation [11].

The observation of microstructure was carried out using optical microscopy (OM) and JEM-2100 transmission electron microscopy (TEM) operated at $200 \mathrm{kV}$. The phase constituent in samples was analyzed by a D/max-2500/PC $\mathrm{X}$-ray diffractometer (XRD) with $\mathrm{Cu} K_{\alpha}$ radiation. Rockwell hardness tests were conducted to measure the integral hardness, and for each sample, the result is the average value of five measured values at different positions.

Different heat treatment procedures were employed including the traditional austempering procedures and selfdeveloped A-P-T process. For traditional austempering, samples were heated to $1100{ }^{\circ} \mathrm{C}$, held for $30 \mathrm{~min}$ and then quenched into 250,280 and $300{ }^{\circ} \mathrm{C}$ salt bath with different time of holding. For the A-P-T process, the austempered samples were quenched into $300{ }^{\circ} \mathrm{C}$ salt bath for $8 \mathrm{~h}$ and then were water cooled to room temperature; subsequently, all the samples were reheated to $300{ }^{\circ} \mathrm{C}$ for $2 \mathrm{~h}$ for the elements diffusion (named as partitioning process) and finally cooled to room temperature by air.

\section{Results and Discussion}

The microstructures of the extra-high-carbon steels subjected to austempering under different conditions are given 

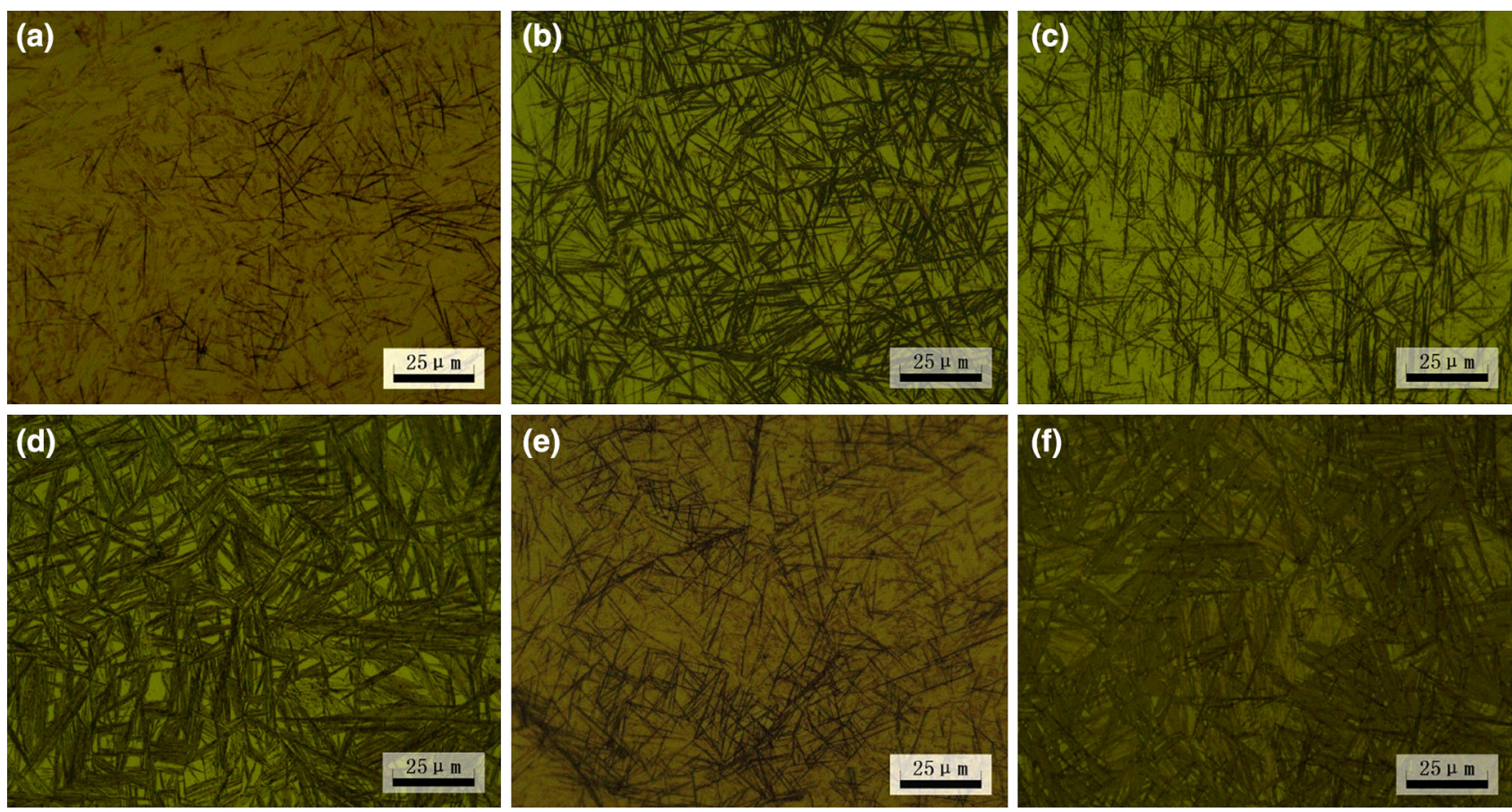

Fig. 2 Optical images of high-carbon alloy steel after austempered at different temperatures for different time: a $300{ }^{\circ} \mathrm{C}, 4 \mathrm{~h}$; b $300{ }^{\circ} \mathrm{C}, 10 \mathrm{~h}$; c $280{ }^{\circ} \mathrm{C}, 10 \mathrm{~h} ; \mathbf{d} 280{ }^{\circ} \mathrm{C}, 20 \mathrm{~h} ;$ e $250{ }^{\circ} \mathrm{C}, 20 \mathrm{~h} ; \mathbf{f} 250{ }^{\circ} \mathrm{C}, 38 \mathrm{~h}$

in Fig. 2, which show a typical morphology of needle-like lower bainite. It can be seen from Fig. 2a that the main phase of the sample is martensite and only a small number of bainite was obtained after isothermally transforming at $300{ }^{\circ} \mathrm{C}$ for $4 \mathrm{~h}$. From Fig. $2 \mathrm{~b}$, it can be found that the bainite needles became longer and crowded and occupied the whole original austenite grains when holding time was extended to $10 \mathrm{~h}$ at $300{ }^{\circ} \mathrm{C}$. It can be concluded that isothermal time can influence the precipitation behavior of carbide from austenite, and the bainitic transformation approximately finished as the holding time was prolonged to $10 \mathrm{~h}$ at $300{ }^{\circ} \mathrm{C}$. The similar results were observed in the samples subjected to austempering at $280{ }^{\circ} \mathrm{C}$ (Fig. 2c, d) and $250{ }^{\circ} \mathrm{C}$ (Fig. 2e, f), but the transformation rates were much slower at lower temperature because it is controlled by the diffusion rate of carbon at $\alpha / \gamma$ interface, which is affected by temperature. Compared the morphologies of fully transformed bainite under various temperatures, bainite needles became finer and denser when holding temperature was reduced from 300 to $250{ }^{\circ} \mathrm{C}$. The possible reason is that the diffusion of carbon becomes harder when the temperature is lower, which restrict the coarsening of bainite.

Figure 3 shows the result of X-ray patterns of samples treated with different procedures, indicating that bainitic ferrite $(\alpha)$ and retained austenite $(\gamma)$ exist in the treated samples. Calibrated diffraction peaks demonstrate that cementite does not appear during the cooling process.

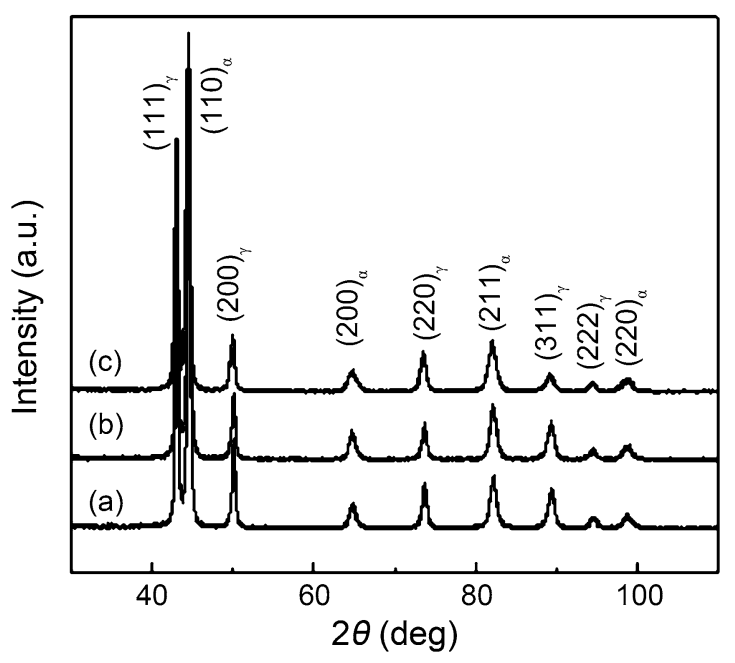

Fig. 3 XRD patterns of the high-carbon steel austempered at different temperatures for different time: a $300{ }^{\circ} \mathrm{C}, 10 \mathrm{~h}$; b $280{ }^{\circ} \mathrm{C}$, $20 \mathrm{~h} ; \mathbf{c} 250{ }^{\circ} \mathrm{C}, 38 \mathrm{~h}$

Volume fraction of retained austenite, $V_{\gamma}$, can be calculated using the equation in Ref. [12]. The results showed that retained austenite contents decreased with the decrease in the austempering temperature. The values were about 61.0 vol\% for $300{ }^{\circ} \mathrm{C} / 10 \mathrm{~h}$ sample, about $55.0 \mathrm{vol} \%$ for $280{ }^{\circ} \mathrm{C} /$ $20 \mathrm{~h}$ sample and about 54.7 vol\% for $250{ }^{\circ} \mathrm{C} / 38 \mathrm{~h}$ sample, respectively. The results are in good agreement with the OM observations in Fig. 2. When the holding time further 

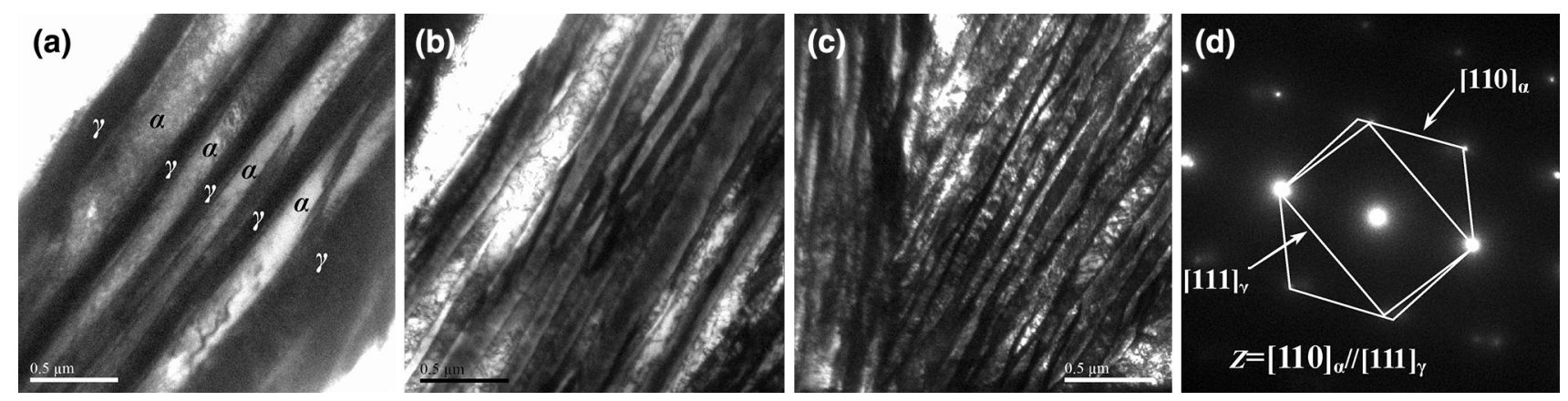

Fig. 4 TEM images of the high-carbon steel austempered at $300{ }^{\circ} \mathrm{C}$ for $10 \mathrm{~h} \mathrm{a}, 280{ }^{\circ} \mathrm{C}$ for $20 \mathrm{~h} \mathbf{b}, 250{ }^{\circ} \mathrm{C}$ for $38 \mathrm{~h} \mathrm{c}$, and the corresponding SAED pattern $\mathbf{d}$ of bainitic ferrite plates and retained austenite
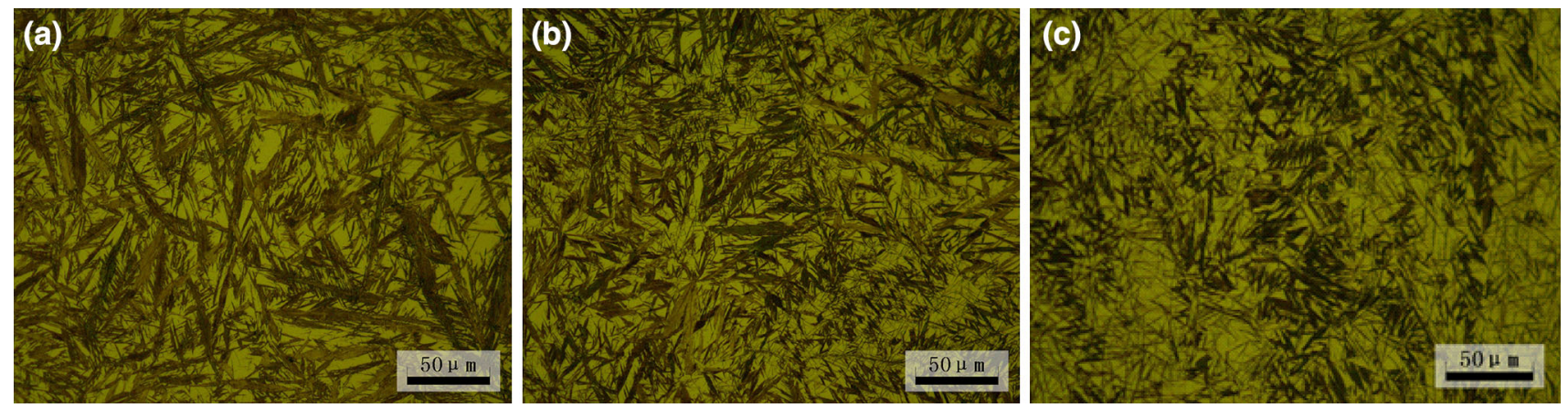

Fig. 5 Optical images of high-carbon steel after austempering-partitioning-tempering treatment: a austempered at $300{ }^{\circ} \mathrm{C}$ for $4 \mathrm{~h}$ and partitioned at $300{ }^{\circ} \mathrm{C}$ for $2 \mathrm{~h}$; b austempered at $300{ }^{\circ} \mathrm{C}$ for $6 \mathrm{~h}$ and partitioned at $300{ }^{\circ} \mathrm{C}$ for $2 \mathrm{~h}$; c austempered at $300{ }^{\circ} \mathrm{C}$ for $8 \mathrm{~h}$ and partitioned at $300{ }^{\circ} \mathrm{C}$ for $2 \mathrm{~h}$

increased and holding temperature further decreased, the volume fraction of retained austenite was decreased. Retained austenite contents in $280{ }^{\circ} \mathrm{C} / 20 \mathrm{~h}$ sample was almost the same as that in $280{ }^{\circ} \mathrm{C} / 38 \mathrm{~h}$ sample, which was different from the reported results [1-3]. No carbide was detected, because the $1.5 \% \mathrm{Si}$ could inhibit the formation, subsequently causing the carbon-enriched retained austensite and bainite.

Figure 4 shows TEM microstructures and the corresponding selected area electron diffraction (SAED) pattern of bainitic ferrite plates and retained austenite. Carbides were not detected, so the bainite can be called carbide-free bainite. The microstructures of the samples in current work are different from the experimental results in Ref. [1]. It may be due to the high-carbon content $(>1 \mathrm{wt} \%)$. The thicknesses of the bainitic ferrite plates are about $150 \mathrm{~nm}$ in $300{ }^{\circ} \mathrm{C}$ treated sample, about $100 \mathrm{~nm}$ in $280{ }^{\circ} \mathrm{C}$ treated sample and about $60 \mathrm{~nm}$ in $250{ }^{\circ} \mathrm{C}$ treated sample, respectively, finer than that was reported in Ref. [4] for the 60Si2CrVA steel. Because of the fine bainitic ferrite plate and the low content of retained austenite, the tensile strength of samples subjected to $250{ }^{\circ} \mathrm{C}$ austempering for $38 \mathrm{~h}$ is the highest, while the ductility is the lowest, as listed in Table 1.

From Table 1, it can be seen that the hardness increased obviously from 47.2 to $53.9 \mathrm{HRC}$ with the decreasing in austempering temperature. The high hardness is due to carbon reinforcement, and carbon solubility in bainitic ferrite is greater than that in equilibrium ferrite [12]. Two factors influenced the hardness variation with the austempering temperature of the treated samples: smaller austenite (soft phase) contents and thinner ferrite plates at low austempering temperature. When austempering temperature was relatively low $\left(250\right.$ and $\left.280{ }^{\circ} \mathrm{C}\right)$, the retained austenite content did not change significantly and the thickness of the ferrite plates played the main role to enhance the hardness. The highest tensile strength is around $2003 \mathrm{MPa}$ for the samples transformed at $250{ }^{\circ} \mathrm{C}$.

Figure 5 demonstrates the duplex microstructure of needle-like bainite and bamboo leaf-shaped martensite. It can be seen from Fig. 5a that when austempering time is short $(4 \mathrm{~h})$, little bainite was transformed, and large martensite formed through the whole prior austenite grains, similar to microstructures obtained by conventional Q-P-T process. With the increase in austempering time, however, needle-like bainite phase appeared and intersected the austenite grains into smaller sizes and therefore refined the size of martensite formed during cooling, as shown in Fig. 5b, c.

Figure 6 shows the duplex microstructure with nanostructured bainite and twin martensite after the A-P-T 

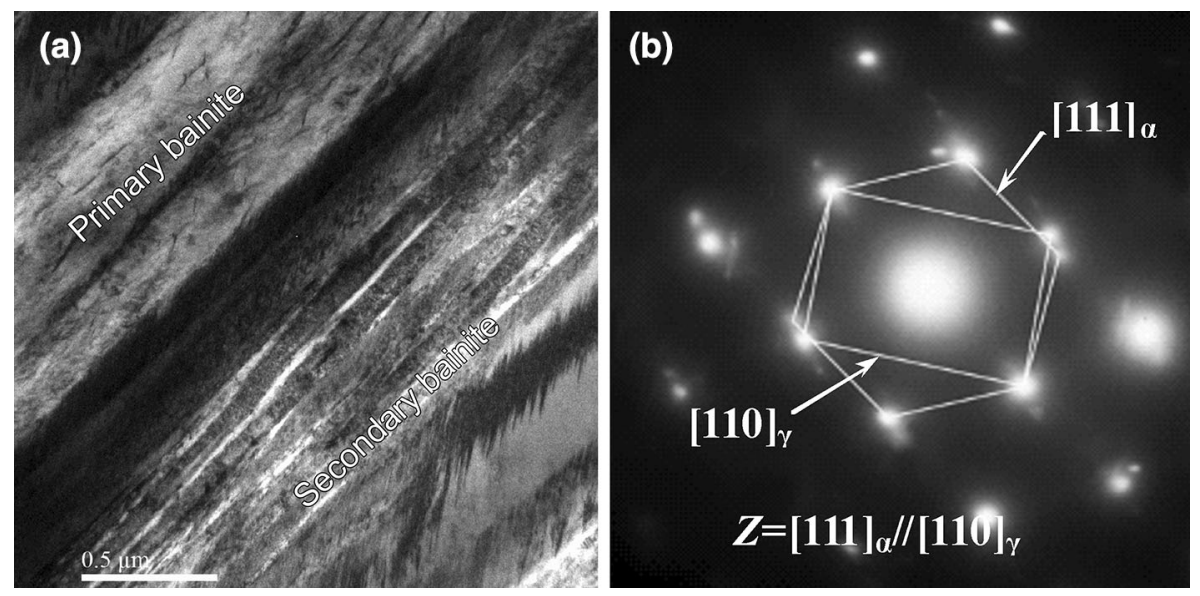

Fig. 6 TEM image of high-carbon steel after austempered at $300{ }^{\circ} \mathrm{C}$ for $8 \mathrm{~h}$ and partitioned at $300{ }^{\circ} \mathrm{C}$ for $2 \mathrm{~h}$ a and the corresponding SAED pattern $\mathbf{b}$

Table 1 Mechanical properties of high-carbon alloy steel under various austempered treatments

\begin{tabular}{lllll}
\hline Treatment & $\begin{array}{l}\text { Yield } \\
\text { strength } \\
(\mathrm{MPa})\end{array}$ & $\begin{array}{l}\text { Tensile } \\
\text { strength } \\
(\mathrm{MPa})\end{array}$ & $\begin{array}{l}\text { Elongation } \\
(\%)\end{array}$ & $\begin{array}{l}\text { Hardness } \\
(\mathrm{HRC})\end{array}$ \\
\hline $300{ }^{\circ} \mathrm{C}$ for $10 \mathrm{~h}$ & 1142.9 & 1467.7 & 4.6 & 47.2 \\
$280{ }^{\circ} \mathrm{C}$ for $20 \mathrm{~h}$ & 1470.5 & 1623.7 & 5.1 & 49.5 \\
$250{ }^{\circ} \mathrm{C}$ for $38 \mathrm{~h}$ & 1677.0 & 2003.1 & 3.2 & 53.9 \\
\hline
\end{tabular}

process. It can be seen that the secondary bainite appeared when the samples reheated at $300{ }^{\circ} \mathrm{C}$ (partitioning). The thickness of the secondary bainitic ferrite plates formed during partitioning is much smaller than that of the primary bainite formed during $300{ }^{\circ} \mathrm{C}$ austempering process (topleft), which may result in higher ductility and toughness.

Mechanical tests were carried out for the steel subjected to the austempering $\left(300{ }^{\circ} \mathrm{C}\right.$ for $\left.8 \mathrm{~h}\right)$-partitioning $\left(300{ }^{\circ} \mathrm{C}\right.$ for $2 \mathrm{~h}$ )-tempering, and the yield strength of $1112 \mathrm{MPa}$, tensile strength of $1533 \mathrm{MPa}$, elongation of $7.4 \%$ and hardness of $48.6 \mathrm{HRC}$ were obtained. Compared to the results in Table 1, it can be concluded that the A-P-T treatment raised the ductility of the steel with some reduction in strength. The mechanical property expressed by the product of tensile strength and total elongation was significantly improved through the A-P-T treatment procedure.

\section{Conclusions}

The thickness of the low-temperature bainitic ferrite plates in the high-carbon steel with $1 \mathrm{wt} \% \mathrm{Cr}$ reduced with the decrease in the austempering temperature, from $150 \mathrm{~nm}$ at
$300{ }^{\circ} \mathrm{C}$ to $60 \mathrm{~nm}$ at $250{ }^{\circ} \mathrm{C}$, and the film-like retained austenite content also reduced, from $61.0 \mathrm{vol} \%$ at $300{ }^{\circ} \mathrm{C}$ to $54.7 \mathrm{vol} \%$ at $250{ }^{\circ} \mathrm{C}$.

The tensile strength and hardness values increased with the decrease in the austempering temperature. The highest tensile strength and hardness values were $2003 \mathrm{MPa}$ and $53.9 \mathrm{HRC}$ for the sample austempered at $250{ }^{\circ} \mathrm{C}$ for $38 \mathrm{~h}$.

The mechanical property of the steel subjected to austempering-partitioning-tempering treatment was significantly improved compared to that subjected to traditional austempering treatment.

\section{References}

[1] F.G. Caballero, H.K.D.H. Bhadeshia, K.J.A. Mawella, D.G. Jones, P. Brown, Mater. Sci. Technol. 18, 279 (2002)

[2] C. Garcia-Mateo, F.G. Caballero, H.K.D.H. Bhadeshia, ISIJ Int. 43, 1821 (2003)

[3] F.G. Caballero, H.K.D.H. Bhadeshia, Curr. Opin. Solid State Mater. Sci. 8, 251 (2004)

[4] T.S. Wang, F.C. Zhang, Y.Z. Zheng, Mater. Sci. Eng. A 438-440, 1124 (2006)

[5] H.Y. Li, X.W. Lu, X.C. Wu, Y.A. Min, X.J. Jin, Mater. Sci. Eng. A 527, 6255 (2010)

[6] Q.G. Hao, Y. Wang, X.S. Jia, X.W. Zuo, N.L. Chen, Y.H. Rong, Acta Metall. Sin. (Engl. Lett.) 27, 445 (2014)

[7] H.F. Lan, L.X. Du, N. Zhou, X.H. Liu, Acta Metall. Sin. (Engl. Lett.) 27, 19 (2014)

[8] Y. Zhao, Q.J. Yan, L.Q. Chen, X.Y. Yuan, Acta Metall. Sin. (Engl. Lett.) 27, 389 (2014)

[9] R.K. Dutta, R.M. Huizenga, M. Amirthalingam, Metall. Mater. Trans. A 45, 218 (2014)

[10] M. Peet, H.K.D.H. Bhadeshia, Materials Algorithms Project. http://www.msm.cam.ac.uk/mapsteel/programs/mucg83.mod. html

[11] K.W. Andrews, J. Iron Steel Inst. 203, 721 (1965)

[12] F.C. Zhang, T.S. Wang, P. Zhang, C.L. Zheng, B. Lv, M. Zhang, Y.Z. Zheng, Scr. Mater. 59, 294 (2008) 